\title{
MINIMAL EXTENSION PHASES OF UNTERAARGLACIER (SWISS ALPS) DURING THE HOLOCENE BASED ON ${ }^{14} \mathrm{C}$ ANALYSIS OF WOOD
}

\author{
ANNE HORMES, ${ }^{1}$ CHRISTIAN SCHLÜCHTER ${ }^{1}$ and THOMAS F. STOCKER ${ }^{2}$
}

ABSTRACT. Tree trunks and wood fragments in minerotrophic fen peat that accumulated as the result of a jökulhlaup in the outwash plain of Unteraarglacier were radiocarbon-dated using conventional B-counting. Different pretreatment methods were tested on two wood samples to determine the reliability of our dates. We dated the wood compounds after extended acidalkali-acid treatment, as well as extraction of cellulose and lignin. The results of the samples Picea (B-6687) and Pinus cembra (B-6699) show insignificant differences of $<1 \sigma$.

The ${ }^{14} \mathrm{C}$ dates represent retreat of Unteraarglacier due to warmer and/or drier phases in the Holocene compared to modern climate conditions. The glacier was at least several hundred meters smaller in extent than today ca. 8100-7670 BP, 6175-5780 $\mathrm{BP}, 4580-4300 \mathrm{BP}, 4100-3600 \mathrm{BP}$ and $3380-3200 \mathrm{BP}$. The ${ }^{14} \mathrm{C}$ dates suggest a ca. 2000-yr cyclicity of tree growth in the area covered by the present Unteraarglacier. The most intense warm and dry period occurred between $4100 \mathrm{BP}$ (probably extending back to $4580 \mathrm{BP}$ ) and $3600 \mathrm{BP}$, with growth of fen peat between 3800 and $3600 \mathrm{BP}$ attributed to wetter conditions.

\section{INTRODUCTION}

A prerequisite for predicting and modeling anthropogenic influences on the environment is the understanding of natural climate variability. Glacier fluctuations are one proxy signal of such variation.

In the summer of 1995, tree stems and disk-like rounded Cyperaceae fen peat fragments were found on the Unteraarglacier's outwash plain at an altitude of $1920 \mathrm{~m}$ asl.; these were clearly eroded from the glacier's bed and transported by an enormous jökulhlaup (glacier outburst flood) event in context with the actual retreat. A study of these samples may contribute to solving the following problems:

1. Dating of glacier extents that must have been smaller than today, because the stems and peat fragments have been eroded by the glacier. Parallel to a smaller glacier extension, the tree line must have been higher than today because no trees are now growing in the glacier's outwash plain and in its junction area. Thus, the samples studied provide clear evidence of an area formerly covered with vegetation.

2. Testing the conformity of ${ }^{14} \mathrm{C}$ dates of different wood components using chemical treatments.

3. Verifying Holocene climate changes reflected in glacier variations. Glacier recession phases represent higher annual-mean temperatures (e.g., Wigley and Kelly 1990) and are applicable for comparison with other climate archives.

4. Verifying the amplitude of Holocene Unteraarglacier variations. The Little Ice Age maximum was reached in 1871 (Guttannen/Siegfriedatlas 1872; Unteraarglacier tongue 1879/80). This was much later than for most Alpine glaciers, due to the geometry of catchment basin.

Investigations into the fluctuations of Unteraarglacier were designed to evaluate the effectiveness of isolated components from wood as dating tools and glacier behavior as a climate signal.

Detailed knowledge of Holocene glacier fluctuations in high mountain areas can be gleaned from dated moraine sequences and historical records, especially maps (e.g., Denton and Karlén 1973; Zumbühl and Holzhauser 1988; Gamper and Suter 1982; Patzelt and Bortenschlager 1973; Patzelt 1996). Due to the recent widespread retreat of Alpine glaciers, more information has become avail-

\footnotetext{
${ }^{1}$ Quaternary Geology, Geological Institute, University of Bern, Baltzerstrasse 1, CH-3012 Bern, Switzerland

${ }^{2}$ Climate and Environmental Physics, University of Bern, Sidlerstrasse 5, CH-3012 Bern, Switzerland
} 
able about glacier contraction phases in the Holocene (Porter and Orombelli 1985; Röthlisberger 1976; Röthlisberger et al. 1980; Schlüchter 1994; data also available from the World Glacier Monitoring Service ${ }^{3}$ ).

\section{Location and Geology of the Study Area}

The Unteraarglacier is situated in the Berner Oberland of Switzerland $\left(46^{\circ} 34^{\prime} \mathrm{N}, 8^{\circ} 12^{\prime} \mathrm{E}\right)$ near Grimselpass; it is formed by the confluence of two glaciers, Lauteraar and Finsteraar. The equilibriumline of the system is presently at $2800 \mathrm{~m}$ altitude (Gudmundsson 1994).

Reconstruction of the minimal extent of the Unteraarglacier during different Holocene phases is not possible based on the present samples, because they were not found in situ. The glacier tongue had to have been several hundred meters shorter than it is now. However, the complete disappearance of the Unteraarglacier is difficult to imagine and $6 \mathrm{~km}$ of ice remains today. The retreat was $1951 \mathrm{~m}$ between 1876 and 1995, with an average value of $-16.9 \mathrm{~m}$ per year (data from World Glacier Monitoring Service).

Reservoir effects hamper radiocarbon dating under certain conditions: bedrock lithology is one critical factor. The Unteraarglacier and its tributaries are situated in the Aarmassiv, a Variscan autochthon massif of the Swiss Alps. Mixed high-grade to anatectic metasedimentary gneisses, orthogneisses, chlorite schists and migmatitic gneisses, as well as ultramafic inclusions and amphibolites, are abundant in the Lauteraar- and Finsteraarglacier catchment area (Abrecht 1994). The Central Aar granite is the main geologic unit in the Unteraarglacier region.

Given this geological setting and the lack of fresh carbonaceous material at the surface of the Unteraarglacier region, reservoir effects are unlikely to be of concern here.

\section{METHODS}

The wood samples were deformed due to transportation in the glacier ice or due to erosive deformation of the glacier bed. The tree rings were compressed and the cell walls, in some cases, destroyed or wavelike. Pebbles and sand grains were sometimes found pressed into the wood. The anatomy of the wood was studied by microscope to determine the wood species (Table 1). The wood samples were air dried, cut with a mechanical saw and stored in distilled water. Slices were later cut with Gillette Super Silver razor blades. Afterwards the thin sections of wood were mounted into a glycerin: ethanol:deionized water (1:1:1) mixture on microslides for identification under the microscope (Schweingruber 1990). The wood macrofossils in the peat were handpicked and handled in the same way.

\section{Chemical Pretreatment}

To avoid contamination, ${ }^{14} \mathrm{C}$ dating is often based on chemically well defined compounds extracted from the wood. Subfossil wood consists mainly of lipids (waxes, fats), resins, sugars, hemicellulose, degraded lignin (30-60\%) and altered cellulose (40-70\%) (Killops and Killops 1993).

Zaitseva (1995) pointed out that lignin and lignoacids (alkali soluble, acid insoluble fraction) do not show significantly different ${ }^{14} \mathrm{C}$ age from Larix and Pinus. Obviously, species-independent dating is therefore possible. Our lignin extraction method is partially based on Zaitseva (1995). Olsson (1980) did experiments on Pinus aristata wood growing between 1835 and 1855. The most reliable

\footnotetext{
${ }^{3}$ World Glacier Monitoring Service, Swiss Federal Institute of Technology, Laboratory of Hydraulics, Hydrology, and Glaciology, Gloriastrasse 37/39, CH-8092 Zurich, Switzerland
} 
dates, yielding reproducible values, were obtained from 1) the insoluble fraction after acid-alkaliacid treatment, 2) the insoluble components after treatment with $\mathrm{NaOH}$, water, methanol and ethanol from heartwood, 3) the alkali insoluble fraction of sapwood and 4) holocellulose.

DeNiro (1981) described the D/H ratios after combustion in oxygen atmosphere using a PekinElmer Model 180 spectrometer, concluding that the $\mathrm{NaClO}_{2}$ method results in the purest cellulose. Hence we used oxidation by $\mathrm{NaClO}_{2}$ to prepare the cellulose.

The outermost 5-10 tree rings of the wood samples were cut into small chips $(<0.5 \mathrm{~cm})$ before chemical treatment. The samples for lignin and cellulose were milled with a carbide mill.

The standard pretreatment at the Bern laboratory is based on, e.g., the studies by Olsson (1980) and Mook and Streurman (1981) and has been extended by Steve Reese with one more alkali step to dissolve contaminants effectively. Hence, pretreatment at the Bern laboratory consists mostly of two acid and two alkali steps. Dilute solutions (4\%) were used to avoid a high loss of sample material. A $4 \%$ solution of $\mathrm{NaOH}$ at a temperature of $25-80^{\circ} \mathrm{C}$ overnight was used to remove tannic acids, lignoacids sensu Zaitseva (1995) and infiltrated humic acids. Lipids such as waxes and fats were removed in a $4 \% \mathrm{HCl}$ solution at a temperature of $80^{\circ} \mathrm{C}$. In addition, sugars, infiltrated carbonate, hemicellulose, pentosanes, proteins, amino acids, amino sugars and possibly modern atmospheric $\mathrm{CO}_{2}$ (dissolved during the alkali step) are removed by acid treatment. The extracts were separated from the residue and removed together with acid or alkali by washing with deionized water until a $\mathrm{pH}$ of 7 was reached. The insoluble residue consists mainly of lignin and cellulose, but residues of lipids, resins and celluloseacetate could have remained in the rest of the treated samples (DeNiro 1981).

Lignin $\left(\left(\mathrm{C}_{8} \mathrm{H}_{17} \mathrm{O}_{6}\right)_{\mathrm{n}}\right)$ is a high-molecular-weight polyphenolic compound, insoluble in water and acid, forming the network around the cellulose fibers (Römpp 1992; Killops and Killops 1993). To remove cellulose, the hemicellulose must be removed first by a standard acid treatment. Then cellulose is converted into celluloseacetate by boiling with $3 \% \mathrm{H}_{2} \mathrm{SO}_{4}+\mathrm{HCl}$ and afterwards stored for 1 $\mathrm{h}$ in $72 \% \mathrm{H}_{2} \mathrm{SO}_{4}+\mathrm{HCl}$ at a temperature of $25^{\circ} \mathrm{C}$ (Zaitseva 1995; Römpp 1992). Treatment with cyclohexane and ethanol 2:1 in a soxhlet extraction apparatus removes the celluloseacetate as well as resins and waxes. After this pretreatment a standard treatment with one alkali and one acid step followed.

Cellulose $\left(\left(\mathrm{C}_{6} \mathrm{H}_{10} \mathrm{O}_{5}\right)_{n}\right)$ is a polysaccharide insoluble in water; it is the main compound in cell walls and provides a rigid layer around the cell membranes. First the waxes, celluloseacetate, and resins were dissolved during a soxhlet extraction with cyclohexane + ethanol 2:1. The second step was an acid step. To destroy the lignin, $30 \mathrm{~g} \mathrm{NaClO}_{2}+1 \mathrm{~mL} 37 \% \mathrm{HCl}$ were added to $50 \mathrm{~g}$ milled wood stored in $0.8 \mathrm{~L}$ deionized water at a temperature of $75^{\circ} \mathrm{C}$. The oxidation step with $\mathrm{NaClO}_{2}$ was repeated until the sample clearly showed a white color. The destroyed substances were removed by means of an alkali step and a final acid step.

Between all chemical steps the samples are washed with deionized water until a $\mathrm{pH}$ of 7 is reached.

\section{Radiocarbon Measurement}

In the underground laboratory of Climate and Environmental Physics at the University of Bern, the low-level gas proportional counting technique is used by converting carbon dioxide into methane (e.g., Polach and Stipp 1967). All samples were counted for $4200 \mathrm{~min}$, except samples B-6703, B6706 (4080 min), B-6687 standard, B-6691, B-6701 (4140 min). ${ }^{14} \mathrm{C}$ ages are reported either as 
uncalibrated BP or cal BP; if corrected and calibrated it is done according to the methods outlined for OxCal by Bronk Ramsey (1995).

\section{RESULTS AND DISCUSSION}

The results of comparative investigations of different treatment methods on two wood samples were very encouraging (Table 1). The difference for the Picea sample (B-6687) amounts to only $90{ }^{14} \mathrm{C}$ yr (4520-4430 BP, $1 \sigma)$. The ${ }^{14} \mathrm{C}$ ages of Pinus cembra (B-6699) extend over a range of only $75 \mathrm{yr}$ (3980-3905 BP, 10).

These results show no significant difference between the different chemical treatment methods. (Bear in mind, however, that the wood samples were preserved under chemically favorable conditions under the glacier.)

The dates obtained cluster in the time windows 8.1-7.7 kyr BP, 6.2-5.8 kyr BP, 4.5-4.3 kyr BP, 4.1$3.6 \mathrm{kyr}$ BP and 3.4-3.2 kyr BP (Fig. 1, Table 1).

$\underline{\text { TABLE 1.Tree Stems and Salix Macrofossils (Fen Peat) of Unteraarglacier }}$

\begin{tabular}{|c|c|c|c|c|c|c|c|}
\hline $\begin{array}{l}\text { Lab code } \\
\text { (B-) }\end{array}$ & $\begin{array}{l}\text { Sample material } \\
\text { (pretreatment method) }\end{array}$ & $\begin{array}{l}\text { Tree } \\
\text { rings }\end{array}$ & $\begin{array}{l}\text { Background } \\
\text { (cpm / 1) }\end{array}$ & $\begin{array}{c}\mathrm{CO}_{2} \\
\text { (mbar) }\end{array}$ & $\begin{array}{l}\delta^{13} \mathrm{C} \\
(900)\end{array}$ & $\begin{array}{l}{ }^{14} \mathrm{C} \text { age } \\
\text { (yr BP) }\end{array}$ & $\begin{array}{c}\text { Calibrated } \\
\text { age* } \\
(\text { cal BP, 20) }\end{array}$ \\
\hline 6691 & Picea / Larix (standard) & 40 & $0.840 \pm 0.006$ & 663 & -26.1 & $8029 \pm 33$ & $8990-8674$ \\
\hline 6690 & Picea / Larix (standard) & 48 & $0.843 \pm 0.009$ & 858 & -27.0 & $7973 \pm 31$ & $8980-8613$ \\
\hline 6686 & Picea (standard) & 76 & $0.843 \pm 0.009$ & 1001 & -26.4 & $7972 \pm 31$ & $8950-8674$ \\
\hline 6692 & Picea / Larix (standard) & 12 & $0.843 \pm 0.009$ & 783 & -25.2 & $7960 \pm 31$ & $8956-8602$ \\
\hline 6700 & Larix sp. (standard) & 90 & $0.843 \pm 0.009$ & $\sim 850$ & -26.2 & $7702 \pm 31$ & $8545-8375$ \\
\hline 6704 & Pinus cembra (standard) & 80 & $1.296 \pm 0.010$ & 601 & -26.4 & $6032 \pm 36$ & $6997-6784$ \\
\hline 6689 & Pinus cembra (standard) & 25 & $0.843 \pm 0.009$ & 827 & -24.3 & $6032 \pm 28$ & $6990-6788$ \\
\hline 6842 & Pinus cembra (lignin) & 70 & $0.843 \pm 0.009$ & 780 & -25.5 & $5804 \pm 28$ & $6718-6506$ \\
\hline 6687 & Picea (lignin) & 65 & $0.843 \pm 0.009$ & 1043 & -25.6 & $4494 \pm 26$ & $5286-4995$ \\
\hline 6687 & Picea (cellulose) & 65 & $0.843 \pm 0.009$ & 872 & -24.3 & $4471 \pm 26$ & $5284-4885$ \\
\hline 6687 & Picea (standard) & 65 & $0.843 \pm 0.009$ & 898 & -26.0 & $4460 \pm 30$ & $5277-4878$ \\
\hline 6707 & Pinus cembra (standard) & 20 & $0.843 \pm 0.009$ & 777 & -26.0 & $4340 \pm 25$ & $4981-4838$ \\
\hline 6703 & Picea (standard) & 60 & $0.843 \pm 0.009$ & 814 & -27.0 & $4045 \pm 25$ & $4565-4422$ \\
\hline 6688 & Larix / Picea (standard) & 65 & $0.843 \pm 0.009$ & 796 & -26.2 & $4039 \pm 25$ & $4562-4421$ \\
\hline 6702 & Picea (standard) & 170 & $0.843 \pm 0.009$ & 706 & -25.5 & $3972 \pm 25$ & $4517-4313$ \\
\hline 6699 & Pinus cembra (cellulose) & 95 & $0.840 \pm 0.006$ & 625 & -23.4 & $3954 \pm 26$ & 4509-4294 \\
\hline 6699 & Pinus cembra (standard) & 95 & $0.840 \pm 0.006$ & 719 & -25.1 & $3945 \pm 26$ & $4505-4286$ \\
\hline 6699 & Pinus cembra (lignin) & 95 & $0.843 \pm 0.009$ & 765 & -25.1 & $3930 \pm 25$ & $4421-4277$ \\
\hline 6697 & Salix sp. (standard) & -- & $0.843 \pm 0.009$ & 858 & -27.3 & $3789 \pm 25$ & $4236-4007$ \\
\hline 6696 & Salix sp. (standard) & -- & $0.843 \pm 0.009$ & 908 & -26.7 & $3778 \pm 25$ & $4231-4001$ \\
\hline 6701 & Pinus cembra (standard) & 130 & $0.843 \pm 0.009$ & 768 & -24.3 & $3761 \pm 25$ & $4227-3992$ \\
\hline 6619 & Fen peat (bulk) & -- & $1.482 \pm 0.023$ & 603 & -31.2 & $3730 \pm 32$ & $4137-3932$ \\
\hline 6705 & Salix sp. (standard) & -- & $1.542 \pm 0.010$ & 494 & -28.7 & $3694 \pm 33$ & $4134-3920$ \\
\hline 6618 & Salix sp. stem (standard) & 25 & $0.841 \pm 0.013$ & 1064 & -27.7 & $3686 \pm 27$ & $4087-3923$ \\
\hline 6694 & Salix sp. (standard) & - & $0.843 \pm 0.009$ & 959 & -27.8 & $3683 \pm 24$ & $4086-3923$ \\
\hline 6698 & Picea / Larix (standard) & 45 & $0.843 \pm 0.009$ & 808 & -23.6 & $3656 \pm 24$ & $4078-3890$ \\
\hline 6693 & Picea (standard) & 100 & $0.843 \pm 0.009$ & 820 & -27.0 & $3641 \pm 24$ & $4072-3867$ \\
\hline 6695 & Salix sp. (standard) & -- & $1.296 \pm 0.010$ & 603 & -23.6 & $3622 \pm 31$ & $4062-3836$ \\
\hline 6891 & Pinus cembra (lignin) & 80 & $0.843 \pm 0.009$ & 765 & -27.2 & $3276 \pm 24$ & $3566-3407$ \\
\hline 6706 & Betula (standard) & 40 & $0.840 \pm 0.006$ & 721 & -27.5 & $3227 \pm 25$ & $3470-3380$ \\
\hline
\end{tabular}

*The OxCal program by Bronk Ramsey (1995, based on Stuiver, Long and Kra 1993) was used for calibration of the ages 


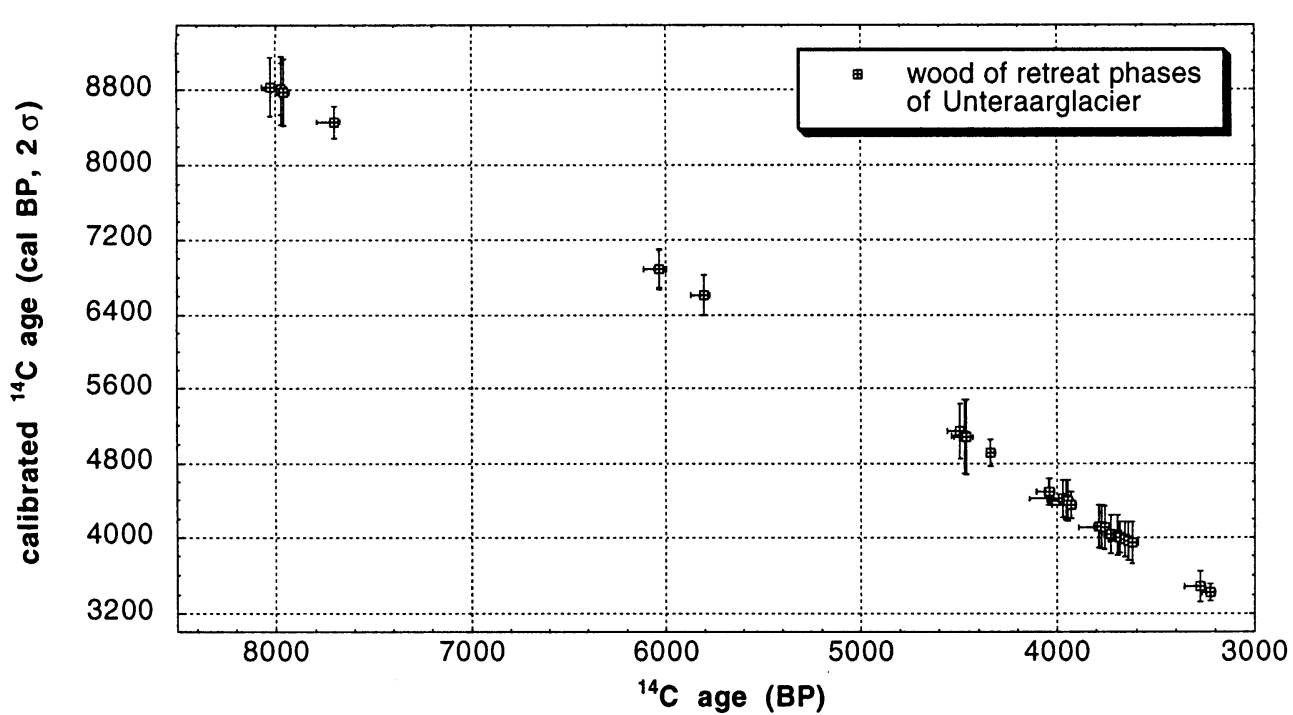

Fig. $1 .{ }^{14} \mathrm{C}$ ages (BP, including the number of tree rings and $1 \sigma$ error) are fitted to their calibrated ages (cal $\mathrm{BP}$ ), using the OxCal program (Bronk Ramsey 1995, based on Stuiver, Long and Kra 1993)

Based on the ${ }^{14} \mathrm{C}$ dating of the wood samples and the number of counted tree rings we can assume a first retreat with a smaller glacier extension than at present between 8100 and $7670 \mathrm{BP}$. Three Picea/ Larix samples of similar age are dated at $7973 \pm 31,7972 \pm 31$ and $7960 \pm 31$ BP. One Larix sp. sample (B-6700) is only slightly different at $7702 \pm 31$ BP (Table 1 ). The Unteraarglacier data confirm previous investigations such as the Holocene history of Swiss glaciers reported by Röthlisberger (1976) and Röthlisberger et al. (1980). They also ${ }^{14} \mathrm{C}$-dated fossil soils and wood found in moraines. The results show similar glacier retreat phases at Gorner-, Zmutt- and Ferpècleglacier in the Alps of Wallis/Switzerland between $8160 \pm 220$ and $7550 \pm 110$ BP (Röthlisberger et al. 1980).

Dendroclimatological investigations on ${ }^{14} \mathrm{C}$-dated floating chronologies demonstrated warm phases in the Swiss Alps between 7740 and 7685 BP as well as between 7610 and 7560 BP (Renner 1982: 157).

Blunier et al. (1995) pointed out in the GRIP ice core a relatively high (ca. $725 \mathrm{ppbv}$ ) methane concentration before $8200 \mathrm{yr}$ ago (ice counted layers) and an abrupt fall at this time. $\mathrm{This}^{\mathrm{C}} \mathrm{CH}_{4}$ dip has recently also been recognized in D47 and Byrd ice cores (Chappellaz et al. 1997; Alley et al. 1997). The GISP2 record shows a relatively stable optimum of $\delta^{18} \mathrm{O}$ values between 9000 and $8500 \mathrm{yr}$ ago. However, an abrupt fall also occurred at 8200 yr ago (Stuiver, Braziunas and Grootes 1995: 346 and Fig. 6). The fall in $\mathrm{CH}_{4}$ concentration as well as $\delta^{18} \mathrm{O}$ happened at around the same time as the alpine glaciers readvanced (e.g., Röthlisberger 1976; Patzelt 1996).

Three Pinus cembra samples of Unteraarglacier were dated between 6030 and $5800 \mathrm{BP}$. This period of glacier contraction $(6140-5780 \mathrm{BP}$, Table 1: counted tree rings included) is reported from other regions as well, based on ${ }^{14} \mathrm{C}$ dates of wood: the Mont Miné glacier and the Ferpècle glacier were smaller before $6020 \pm 100 \mathrm{BP}$; the Allalinglacier was smaller than in the year 1920 before $5760 \pm$ 120 BP (Röthlisberger et al. 1980). Even the glaciers of the Eastern Alps experienced a recession (Patzelt 1996); moreover, in Alaska in the St. Elias Mountains a glacier contraction occurred during 6175-5975 BP (Denton and Karlén 1973). At Alpe d'Essertse in the Central Swiss Alps, charcoal derived from Pinus cembra was found at $2380 \mathrm{~m}$ altitude (50-100 $\mathrm{m}$ above the recent timberline) and yielded a ${ }^{14} \mathrm{C}$ date of $6010 \pm 70 \mathrm{BP}$ (Tinner, Ammann and Germann 1996). 
The $\delta^{18} \mathrm{O}$ record of GISP2 shows slightly higher values relative to the average $\delta^{18} \mathrm{O}$ in the time period 6997-6506 cal BP (cf. Table 1) (Stuiver, Braziunas and Grootes 1995: Fig. 6).

A warm period was documented with one Picea sample (4494-4471 BP with various pretreatment methods, B-6687) and one Pinus cembra sample (B-6707 $=4340 \pm 25 \mathrm{BP})$. This climate change is also reflected in the $\mathrm{CH}_{4}$ records of GRIP, GISP2, D47 and Byrd ca. $5000 \mathrm{yr}$ ago (in comparison with our ${ }^{14} \mathrm{C}$ ages $c a .4500 \mathrm{BP}$ ), when $\mathrm{CH}_{4}$ concentration increased from $35 \pm 7$ ppbv to $50 \pm 3$ ppbv (Chappellaz et al. 1997). At the same time (4600-4000 BP), a Pinus cembra forest developed in the outwash plain of Ferpècle glacier (Röthlisberger 1976). Using the dendroclimatological method, Renner (1982) identified a warm phase at $4395-4330$ BP. The climate signals in the Western and Eastern Alps seem to be different, because the Ötztal ice man died in the Eastern Alps/South Tirol due to a cold phase beginning ca. $4535 \pm 60 \mathrm{BP}$ (ETH-8345.3, grass sample) (Bonani et al. 1994: 248). (Or the finding requires another interpretation if the Ötztal ice man does not indicate the beginning of a cold phase.)

The most striking period of glacier recession of Unteraarglacier (Figs. 1 and 2, Table 1) is the period in the mid-Holocene between $4045 \pm 25$ and $3622 \pm 31$ BP. The greatest number of dated samples, 15 out of 25, cluster in this time period. Also, the climate was warm enough (and possibly with increased precipitation) for a Cyperaceae peat with Salix sp., Alnus (not yet dated) and Betula (not yet dated) species to arise in the period between $3789 \pm 25$ and $3622 \pm 31$ BP. The remarkable onset of peat growth could be attributed to a climate change at $c a .3800$ BP with wetter conditions. Caulfield, O'Donnell and Mitchell (1998) pointed out that at $3800 \mathrm{BP}$ in west Ireland the decline of pine growth also happens very quickly and peat growth is renewed.

Nowhere in the Alps have glacier advances been observed between ca. 4000 and 3600 BP (Gamper and Suter 1982). Indications of smaller glacier extensions than today have been found in the Wallis (Swiss Alps) between $4030 \pm 250 \mathrm{BP}$ and $3350 \pm 80$ BP (Röthlisberger et al. 1980: 43-44) and recently in the Berner Oberland at Stein- and Steinlimmiglaciers and in the Val Malenco, Italy at Lago di Musella ca. 4000 BP (Schlüchter 1994). Even the glaciers in Alaska were smaller ca. 4030 3300 BP (Denton and Karlén 1973). Using the dendroclimatological method, Renner (1982) identi-

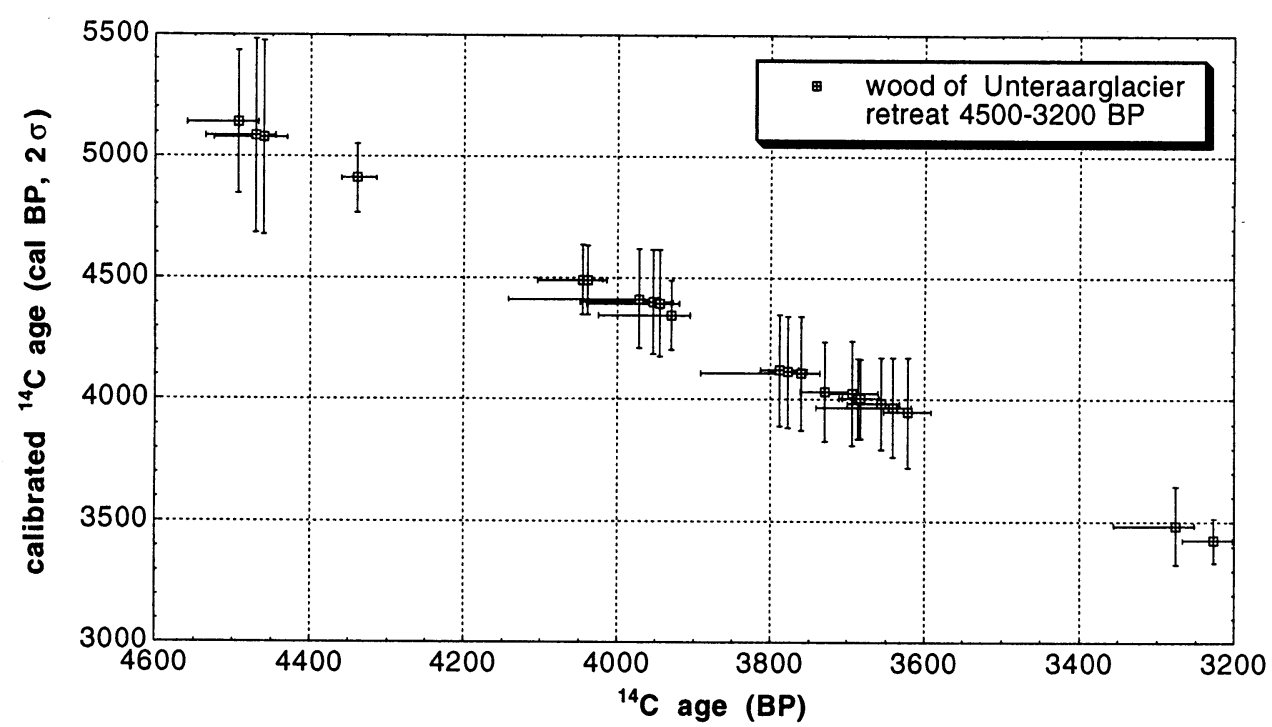

Fig. 2. Fitted ${ }^{14} \mathrm{C}$ ages as in Fig. 1 
fied a higher-than-average warm period between 3740 and $3600 \mathrm{BP}$. Even the $\delta^{18} \mathrm{O}$ values of GISP2 are high in the mid-Holocene (Stuiver, Braziunas and Grootes 1995: Fig. 6).

There is a small remarkable gap between the ${ }^{14} \mathrm{C}$ ages ca. 4.3-4.1 kyr BP (Fig. 2). It could be interpreted as a gap in the numbers of retrieved wood samples, yet it could also represent glacier advance. Renner (1982) found indication of a climate depression at 4130-4070 BP based on density investigations of conifer latewood. But synchronous drier climate conditions are also registered in Western Ireland between 4600 and 3800 BP without a gap, based on ${ }^{14} \mathrm{C}$ dating of 44 pine samples in North Mayo (Caulfield, O'Donnell and Mitchell 1998), and in Northern Scotland between 4405 and 3815 BP (Gear and Huntley 1991). At Alpe d'Essertse in the Wallis, Switzerland the forest limit descended after 4700 BP (Tinner, Ammann and Germann 1996). Therefore we suggest that between 4.3 and $4.1 \mathrm{kyr}$ BP there might be a gap in the amount of samples and the climate conditions were more favorable between $c a .4580$ and $3600 \mathrm{BP}$.

There is little evidence in the literature for a warm period between 3380 and $3200 \mathrm{BP}$, but it exists at Unteraarglacier (Table 1, tree rings and ${ }^{14} \mathrm{C}$ dates $+1 \sigma$ error). Only at Allalinglacier a buried soil of $3270 \pm 135 \mathrm{BP}$ indicates that the glacier had a smaller extension and afterwards the soil was buried due to a readvance (Röthlisberger et al. 1980). Dendroclimatological results also indicate warmer climate conditions between 3340 and 3175 BP (Renner 1982: 53).

The time intervals between ${ }^{14} \mathrm{C}$ date clusters of wood from Unteraarglacier are $2400-1800 \mathrm{yr}, 2000$ $1700 \mathrm{yr}, 1600-1400 \mathrm{yr}, 346 \mathrm{yr}$ and $295 \mathrm{yr}$ (Table 1). The first three intervals suggest a ca. 2000-yr cyclicity.

The $\delta^{18} \mathrm{O}$ record of the GISP2 ice core shows increases of $\delta^{18} \mathrm{O}$ that are forced by spectral power density of the sun and oceanic thermohaline circulation near 3300, 1050, 550, 465, 314, 264, 242, 211,155 and $120 \mathrm{yr}$ (Stuiver, Braziunas and Grootes 1995). Also, studies of cosmogenic ${ }^{14} \mathrm{C}$ content in tree rings due to variations in solar activity found major anomalies with a 2000 -yr periodicity (Stuiver and Reimer 1993; Dergachev and Chistyakov 1995). Finally, the $1374 \pm 502$ yr cycle found in North Atlantic deep sea cores (Bond et al. 1997) seems to coincide with Unteraarglacier, except for the peak of ice-rafted debris at $4200 \mathrm{BP}$. We would like to stimulate the discussion of whether any cycles from $\delta^{18} \mathrm{O}$ records (Stuiver and Braziunas 1993; Stuiver, Braziunas and Grootes 1995) or ${ }^{14} \mathrm{C}$ content variations are reflected in the Unteraarglacier behavior.

\section{Conclusion}

The ${ }^{14} \mathrm{C}$ dates of a set of samples from Unteraarglacier, which reflect glacier contraction phases $(8100-7670 \mathrm{BP}, 6175-5780 \mathrm{BP}, 4580-4300 \mathrm{BP}, 4100-3600 \mathrm{BP}$ and $3380-3200 \mathrm{BP})$ are comparable to several other Holocene climate archives:

1. Glaciers in the Swiss Alps and Alaska (Röthlisberger et al. 1980; Schlüchter 1994; Denton and Karlén 1973): recession phases are recorded 8160-7550 BP, 6020-5760 BP and 4030-3300 BP.

2. Dendroclimatological investigations (Renner 1982): warm phases in the Swiss Alps are noted during $7740-7685 \mathrm{BP}, 7610-7560 \mathrm{BP}, 4395-4330 \mathrm{BP}$ and $3740-3600 \mathrm{BP}$.

3. The contraction of Unteraarglacier between 8029 and 7702 BP (8990-8375 cal BP, \pm 2 o) coincides with high methane concentrations (ca. $725 \mathrm{ppbv}$ ) in the GRIP ice core (Blunier et al. 1995 ) and with a stable optimum in $\delta^{18} \mathrm{O}$ values in the GISP2 ice core (Stuiver, Braziunas and Grootes 1995).

4. The contractions seem to reflect a 2000 -yr periodicity that was also found in cosmogenically produced ${ }^{14} \mathrm{C}$ variations in tree rings by Fourier analysis (Dergachev and Chistyakov 1995). 
5. However, the most conspicuous feature in our Holocene chronology oscillations of Unteraarglacier is the period between 4100 (probably extending back to 4580 ) and $3600 \mathrm{BP}$. A 500-yr (probably 980-yr) period of Holocene optimum climate conditions seems to be a striking event across the Northern Hemisphere (Swiss Alps, Alaska, West Ireland, Northern Scotland, $\delta^{18} \mathrm{O}$ of GISP2). Whether this event is also existent in the mid-latitudes of the Southern Hemisphere and in the tropical regions has yet to be proven.

\section{ACKNOWLEDGMENTS}

We would like to express our sincere thanks to Steve Reese and Markus Möll for combustion, $\mathrm{CO}_{2-}$ reduction, measurement and help in the laboratory, as well as for many critical and stimulating discussions. We thank Werner Schoch for help in determination of the wood samples, and Martin Hoelzle and the World Glacier Monitoring Service for putting the data about the variations in length of Unteraarglacier at our disposal. This paper has benefited greatly from comments on drafts of this paper by William Shotyk and a review of an anonymous reviewer. We also thank Dominik Weiss for his advice in solving the chemical problems and Sascha Bleuler, Kathrin Däniker, Emanuel Morgenthaler, Beat Schlüchter and Raphael Wüst for their help in carrying tons of samples. We acknowledge the KW Oberhasli for the motorboat and their interest in our study.

\section{REFERENCES}

Abrecht, J. 1994 Geologic units of the Aar massif and their pre-Alpine rock associations: A critical review. Schweizerische Mineralogische und Petrographische Mitteilungen 74: 5-27.

Alley, R. B., Mayewski, P. A., Sowers, T., Stuiver, M., Taylor, K. C. and Clark, P. U. 1997 Holocene climate instability: A widespread event 8200 yr ago. Geology 25: $483-486$.

Blunier, T., Chappellaz, J., Schwander, J., Stauffer, B. and Raynaud, D. 1995 Variations in atmospheric methane concentration during the Holocene epoch. Nature 374: 46-49.

Bonani, G., Ivy, S. D., Hajdas, I., Niklaus, T. R. and Suter, M. 1994 AMS ${ }^{14} \mathrm{C}$ age determinations of tissue, bone and grass samples from the Ötztal ice man. Radiocarbon 36(2): 247-250.

Bond, G., Showers, W., Cheseby, M., Lotti, R., Almasi, P., DeMenocal, P., Priore, P., Cullen, H., Hajdas, I. and Bonani, G. 1997 A pervasive millennial-scale cycle in North Atlantic Holocene and Glacial climates. Science 278: 1257-1266.

Bronk Ramsey, C. 1995 Radiocarbon calibration and analysis of stratigraphy: The OxCal program. In Cook, G. T., Harkness, D. D., Miller, B. F. and Scott, E. M., eds., Proceedings of the 15 th International ${ }^{14} \mathrm{C}$ Conference. Radiocarbon 37(2): 425-430.

Caulfield, S., O'Donnell, R. G. and Mitchell, P. I. 1998 ${ }^{14} \mathrm{C}$ dating of a neolithic field system at Céide fields, County Mayo, Ireland. In Mook, W. G. and van der Plicht, J., eds., Proceedings of the 16th International ${ }^{14} \mathrm{C}$ Conference. Radiocarbon, this issue.

Chappellaz, J., Blunier, T., Kints, S., Dällenbach, A., Barnola, J.-M., Schwander, J., Raynaud, D. and
Stauffer, B. 1997 Changes in the atmospheric $\mathrm{CH}_{4}$ gradient between Greenland and Antarctica during the Holocene. Journal of Geophysical Research, in press.

DeNiro, M. J. 1981 The effects of different methods of preparing cellulose nitrate on the determination of the $\mathrm{D} / \mathrm{H}$ ratios of non-exchangeable hydrogen of cellulose. Earth and Planetary Science Letters 54: 177185.

Denton, G. H. and Karlén, W. 1973 Holocene climatic variations - their pattern and possible cause. Quaternary Research 3: 155-205.

Dergachev, V. and Chistyakov, V. 1995 Cosmogenic radiocarbon and cyclical natural processes. In Cook, $G$. T., Harkness, D. D., Miller, B. F. and Scott, E. M., eds., Proceedings of the 15 th International ${ }^{14} \mathrm{C}$ Conference. Radiocarbon 37(2): 417-424.

Gamper, M. and Suter, J. 1982 Postglaziale Klimageschichte der Schweizer Alpen. Geographica Helvetica 37(2): 105-114.

Gear, A. J. and Huntley, B. 1991 Rapid changes in the range limits of Scots pine 4000 years ago. Science 251: 554-547.

Gudmundsson, G. H. 1994 Converging glacier flow - a case study: The Unteraarglacier. Mitteilungen der Versuchsanstalt für Wasserbau, Hydrologie und Glaziologie der Eidgenössischen Technischen Hochschule Zürich 131: 120 p.

Guttannen, Switzerland 1872 [topographic map] Siegfriedatlas sheet XIII. Henri L'Hardy. Original survey, scale 1:50,000.

Killops, S. D. and Killops, V. J. 1993 An Introduction to Organic Geochemistry. New York, Wiley: 265 p.

Mook, W. G. and Streurman, H. J. 1981 Physical and 
chemical aspects of radiocarbon dating. In Mook, W. G. and Waterbolk, H. T., eds., ${ }^{14} \mathrm{C}$ and Archaeology. PACT 8. Strasbourg, Conseil de l'Europe: 31-55.

Olsson, I. U. $1980{ }^{14} \mathrm{C}$ in extractives from wood. In Stuiver, M. and Kra, R. S., eds., Proceedings of the 10th International ${ }^{14} \mathrm{C}$ Conference. Radiocarbon 22(2): 515-524.

Patzelt, G. (with contributions by Bortenschlager, S. and Poscher, G). 1996 Tirol: Ötztal-Inntal. DEUQUA-Exkursion A1. Innsbruck, Institut für Hochgebirgsforschung: $23 \mathrm{p}$.

Patzelt, G. and Bortenschlager, S. 1973 Die postglazialen Gletscher- und Klimaschwankungen in der Venedigergruppe (Hohe Tauern, Ostalpen). Zeitschrift für Geomorphologie Neue Folge, Supplement 16: 25-72.

Patzelt, G. and Bortenschlager, S. 1976 Die postglazialen Gletscher- und Klimaschwankungen in der Venedigergruppe (Hohe Tauern, Ostalpen). Zeitschrift für Gletscherkunde und Glazialgeologie 9(1-2).

Polach, H. A. and Stipp, J. J. 1967 Improved synthesis techniques for methane and benzene radiocarbon dating. International Journal of Applied Radiation and Isotopes 18: 359-364.

Porter, S. C. and Orombelli, G. 1985 Glacier contraction during the middle Holocene in the western Italian Alps: Evidence and implications. Geology 13: 296298.

Renner, F.-B. (ms.) 1982 Beiträge zur Gletschergeschichte des Gotthardgebietes und dendroklimatologische Analysen an fossilen Hölzern. Inaugural-Dissertation, University of Zürich: $180 \mathrm{p}$.

Römpp, H. 19921992 Römpp Chemie Lexikon. 9 vol. Ed. Falbe, J. and Regitz, M. Stuttgart, Georg Thieme Verlag: $4835 \mathrm{p}$.

Röthlisberger, F. 1976 Gletscher- und Klimaschwankungen im Raum Zermatt, Ferpècle und Arolla. In Schneebeli, W. and Röthlisberger, F., eds., 8000 Jahre Walliser Gletschergeschichte. Bern, Schweizer Alpen Club: 59-150.

Röthlisberger, F., Haas, P., Holzhauser, H., Keller, W., Bircher, W. and Renner, F. 1980 Holocene climatic fluctuations - Radiocarbon dating of fossil soils (fAh) and woods from moraines and glaciers in the Alps. Geographica Helvetica 35(5): 21-52.

Schlüchter, C. 1994 Die grünen Alpen vor 2000 Jahren. Cratschla (Zernez) 1995: 60.

Schweingruber, F. H. 1990 Anatomie Europäischer Hölzer: Ein Atlas zur Bestimmung Europäischer Baum-, Strauch- und Zwergstrauchhölzer. Bern, Paul Haupt: $800 \mathrm{p}$.

Stuiver, M. and Becker, B. 1993 High-precision decadal calibration of the radiocarbon time scale, AD 19506000 BC. In Stuiver, M., Long, A. and Kra, R. S., eds., Calibration 1993. Radiocarbon 35(1): 35-65.

Stuiver, M., Braziunas, T. F. and Grootes, P. M. 1995 The GISP2 $8^{18} \mathrm{O}$ Climate record of the past 16,500 years and the role of the sun, ocean and volcanoes. Quaternary Research 44: 341-354.

Stuiver, M., Long, A. and Kra, R. S., eds. 1993 Calibration 1993. Radiocarbon 35(1): 1-244.

Stuiver, M. and Reimer, P. J. 1993 Extended ${ }^{14} \mathrm{C}$ data base and revised CALIB $3.0{ }^{14} \mathrm{C}$ age calibration program. In Stuiver, M., Long, A. and Kra, R. S., eds., Calibration 1993. Radiocarbon 35(1): 215-230.

Tinner, W., Ammann, B. and Germann, P. 1996 Treeline fluctuations recorded for 12,500 years by soil profiles, pollen and plant macrofossils in the Central Swiss Alps. Arctic and Alpine Research 28(2): 131-147.

Unteraarglacier tongue, Switzerland 1879/80 [topographic map] Siegfriedatlas sheet XVIII Nr. 414. Fridolin Becker. Original survey, scale 1:50,000.

Wigley, T. M. L. and Kelly, P. M. 1990 Holocene climatic change, ${ }^{14} \mathrm{C}$ wiggles and variations in solar irradiance. Philosophical Transactions of the Royal Society, London A330: 547-560.

Zaitseva, G. I. 1995 Chemical composition and sample preparation of archaeological wood for radiocarbon dating. In Cook, G. T., Harkness, D. D., Miller, B. F. and Scott, E. M., eds., Proceedings of the 15 th International ${ }^{14} \mathrm{C}$ Conference. Radiocarbon 37(2): 311317.

Zumbühl, H. J. and Holzhauser, H. 1988 Alpengletscher in der Kleinen Eiszeit. Sonderheft "Die Alpen" 3. Bern, Schweizer Alpen Club: 322 p. 